\section{Önitatók konstrukciós és hidromechanikai vizsgálata}

\author{
Dávidházy Gábor \\ Tessedik Sámuel Főiskola, Mezőgazdasági Főiskolai Kar, \\ Géptani Tanszék, Mezőtúr
}

- CÉLKITÜZÉS: a hazai szarvasmarhatartásban alkalmazott önitatók konstrukciós és hidromechanikai vizsgálata, LABORATÓRIUMI és ÜZEMI KÖR̈̈LMÉNYEK között.

- Vizsgálati és minósitési szabvány hiányában az önitatóberendezések ÚJ VIZSGALATI MÓDSZERÉT és MINŐSÍTÉSÉT dolgoztam ki.

- A LABORATÓRIUMI MÉRÉSEK elvégzésére univerzális mérőpultot terveztem és állitottam össze, mely alkalmas valamennyi típusú (szarvasmarha, juh, sertés) önitató berendezés hidromechanikai vizsgálatára.

- A LABORATÓRIUMI MÉRÉSEK ÖSSZEFOGLALÁSA alapján megállapitottam, hogy az önitató szelepek átbocsátóképessége a nyomás függvényében exponenciálisan változik, de csak a legnagyobb áteresztöképességü szelep értékelhetö úgy, hogy az eléri a kifejlett szarvasmarha számára szükséges ivási sebesség biztositását.

- AZ ÜZEMI VIZSGÁLATOK ÖSSZEFOGLALÁSA alapján megállapitottam, hogy az egyedi szelepes berendezések közül legjobb üzembiztossági mutatókkal a gumihevederes és a gumirugós önitatók rendelkeznek. Ez alátámasztja a gumi alkalmazásának lényegesen szélesebb körü alkalmazását a különbözö szelepszerkezeteknél, melyet számos külföldi országban már elterjedten alkalmaznak.

- A gumirugós önitatóra vonatkozó mérési eredményeim alapján annak konstrukcióját mélyrehatóbban elemeztem és átalakítottam a következö cél érdekében:

- $\xi_{s z}$-veszteségtényezö csökkentése,

- $\quad$-átbocsátóképesség növelése kisebb nyitási viszonynál, illetve alacsonyabb nyomástartományban is.

\section{SUMMARY}

Our research aimed to examine Hungarian automatic drinking system constructions and hydromechanics under laboratory conditions and in operation with special emphasison the small volume, valve types.

Considering that no Hungarian standard of automatic drinking system examination and qualification exists, on the basis of technical literature, the new examination method of automatic drinking systems has been elaborated.

For laboratory measurements, a universal measuring bench was assembled which is applicable to the hydromechanic testing of all automatic drinking systems (cattle, sheep, pig).

Summary of the laboratory measurements:

Upon comparison of the flow capacity of the valves, in the case of same opening values $\left(h / d_{n}\right)$, the rubber spring valve of SZI type automatic fountain has the highest flow capacity, although in the case of $100 \mathrm{kPa}$ pressure even this type has only 15-16 l/min value which hardly surpasses the lower limit of the desired 15-25 $l /$ min range.

The loss coefficients of the valves, on investigating in the range 100-200 $\mathrm{kPa}$, showed the lowest value $(2,2-5,8)$ with the steel spring self drinking device.
Summary of the operational investigations:

In the long term operational investigations, the rubber stripped valve and the rubber spring automatic fountains had the most favourable operational reliability values: $K_{4}=0,98$ and $K_{4}=0,94$, respectively.

From the aspect of animal operation of the valves, all the Hungarian types are frontal operated, thus such system automatic valve drinking devices can be used only in long and moderately long stands, directed toward the animal.

On the basis of hydromechanical and construction examinations of the Hungarian tied cattle production technology the construction modification of the rubber spring valve of SZI type automatic drinking fountain, which is the most frequantly used in this country, was carried out. Due to design modifications the valve parameters improved significantly.

The goals of the accomplished valve modification were

$\zeta_{s z}$ - loss coefficient to be reduced

$q$-flow capacity to be increased

\section{IRODALMI ÁTTEKINTÉS}

\section{a. A téma felvetése, jelentősége és aktualitása}

Köztudott tény, hogy az állatok alapvető életfunkcióinak ellátásához nélkülözhetetlen a víz és döntő befolyással van a termelésre. A korlátozott vízfelvétel csökkenti a táplálékfelvételt, amely negatívan hat a fiatal állatok növekedésére, vagy a felnőtt állatok termelésére. $\mathrm{Az}$ állatok vízszükségletüket ivóvízzel, a takarmánnyal felvett vízzel és a különféle táplálékok elégetésével keletkező ún. oxidációs vízzel biztosítják. Közérzetük legjobb akkor, ha tetszés szerinti időben és mennyiségben ihatnak (Komjáthy, 1996).

Ahhoz, hogy az állatok ivóvízigényét megfelelő műszaki berendezésekkel kielégítsük, szükséges élettani igényeik ismerete (Horn, 1995).

Az állatok tartásmódja alapvetően meghatározza egy állattartó telep gépesítését is. (Saját vizsgálatok az USA Pennsylvania államában, 1993, 1996, 2000-ben.)

1973 óta foglalkozom a szarvasmarhatartás technológiai gépeinek üzemi vizsgálatával (Dávidházy-Patkós, 1974; Dávidházy-Patkós, 1975; Dávidházy-Dolina, 1976; Dávidházy-Varga, 1980), ezen belül is kiemelten az önitató-berendezésekkel (Dávidházy, 1980; Dávidházy, 1982; Dávidházy, 1983; Dávidházy, 1984; Dávidházy, 1985; Dávidházy, 1986). Megfigyeléseim és eddigi vizsgálataim szerint ezen berendezések kialakításánál sok esetben nem, vagy nem kellő mértékben vették figyelembe az állat igényeit, szokásait. Az etológiai vizsgálatok eredményei alapján ezeket a gépeket és berendezéseket felül kell vizsgálni. Szükség esetén azokat módosítani, illetve 
más gépekkel kell helyettesíteni (Dávidházy, 1993; Dávidházy, 1994; Dávidházy, 1995; Dávidházy, 1996; Dávidházy, 1997).

A szarvasmarha itatására vonatkozó külföldi (Boxberger-Zips, 1979; Castle-Thomas, 1975; Metzner, 1978) és hazai vizsgálatok (Gere, 1996; Kocsis, 1981; Komjáthy, 1996; Mikecz-Czakó, 1977) megállapításai alapján szükséges a jelenleg használt - elsősorban szelepes rendszerü - önitató berendezések felülvizsgálata és olyan konstrukciók kialakítása, melyek a szarvasmarhák igényeinek (ivási viselkedés és mozgásfolyamatok) jobban megfelelnek.

Az itató-berendezések egy része nem biztosítja a természetes ivási lehetőséget, $\mathrm{s}$ ebből adódóan a napi vízfogyasztás $26-31 \%$-kal kisebb lehet, mint a természetes igény lenne. Mivel a szelepes önitató berendezéseket a kis víztér jellemzi, az állatok ivási sebességét a szelepek átbocsátó-képessége és a vízhálózat nyomása határozza meg (Patkós-Tóth, 1978). Külföldi és hazai kutatók a szarvasmarha ivási sebességére 15-25 1/min intervallumot adnak meg, mely azonban a fajtától és az egyedektől függően szélsőséges esetekben ennél nagyobb értéket is elérhet. Egybehangzó megállapításként fogalmazódik meg az az igény, hogy az önitató berendezések vízkészletét, valamint a vízutánfolyást összhangba kell hozni a szarvasmarha ivási sebességével és a vízfelvétel mennyiségével. Nem elhanyagolható szempont a különböző kialakítású és méretü berendezések megfelelő elhelyezése sem.

\section{b. Célkitűzések}

Célul tüztem ki a hazai szarvasmarhatartásban alkalmazott önitatók konstrukciós és hidromechanikai vizsgálatát, laboratóriumi és üzemi körülmények között, különös tekintettel a kisvízterű szelepes önitató-berendezésekre.

\section{Célkitüzéseim:}

- Az önitató-berendezések hidromechanikai jellemzőinek meghatározása,

- A konstrukciók gyenge pontjainak feltárása és megállapítása,

- Összehasonlító értékelés alapján javaslattétel hidromechanikai és

konstrukciós változtatásokra, új önitatók kialakítására.

\section{VIZSGÁLATI ANYAG ÉS MÓDSZER}

\subsection{Mérővizsgálati tematika}

$\mathrm{Az}$ önitató-berendezések vizsgálatát és minősítését meghatározó szabvány hazánkban még nem áll rendelkezésre. E vizsgálati és minősítési szabvány hiányában a szakirodalom és a hazai tapasztalatok széleskörü figyelembevételével az önitató-berendezések új vizsgálati módszerét dolgoztam ki.

A LABORATÓRIUMI MÉRÉSEK elvégzésére univerzális mérôpultot terveztem és állítottam össze, mely alkalmas valamennyi típusú (szarvasmarha, juh, sertés) önitató berendezés hidromechanikai vizsgálatára.

A mért adatokból a berendezésekre jellemző olyan hidromechanikai jellemzőket határoztam meg, melyeket az eddig végzett hazai vizsgálatok nem tartalmaznak.

A vizsgált berendezések az SZI (acél és gumirugós változata) a P-1, D-01 szelepes és a NIVÓ I-II, PCSSZ I-II, valamint az általunk kifejlesztett szinttartásos önitató berendezések voltak.

A vizsgálatokat minden típusnál azonos 20-300 $\mathrm{kPa}$ (0,2-3,0 bar) méréstartományban végeztem el, 20 $\mathrm{kPa}-\mathrm{os}$ osztásközzel. A szelepek nyitási viszonyait ugyancsak azonos módon állítottam be a mérési eredmények összehasonlíthatósága miatt, egyedileg erre a célra készített csavarorsós készülékkel.

A laboratóriumi méréseket alapvetően két fö csoportba osztottam:

a/ A szelepes rendszerü önitató-berendezések vízátbocsátó képességének mérése a szelepek kiszerelt állapotában, különböző nyitási viszonyok esetén.

b/ A szelepes és szinttartásos rendszerü önitató berendezések feltöltődési idejének mérése üzemszerü állapotban.

Az eredeti és az átalakított önitatóberendezések üzemi vizsgálatát az MGI 39-7-72 számú „Szarvasmarhatelepek műszaki-ökonómiai vizsgálata" háziszabványának felhasználásával a tiszaföldvári Tiszapart, a nagyrévi Tiszazug Mezőgazdasági Termelőszövetkezet, a Közép-tiszai Állami Gazdaság szakosított szarvasmarha telepein, valamint Hajdú Bihar-, Jász-Nagykun Szolnok-, Békés- és Somogy megye családi gazdaságaiban folyamatosan végeztem, melyből mélyebben egy $T_{1}$ $=720$ óra üzemeltetési periódus részletes vizsgálatát emelek ki. Ezen időtartamban rögzítettem a berendezéseknél előfordult müszaki és technológiai hibákat, annak okait, a kijavítás módját és időtartamát.

A laboratóriumi és üzemi vizsgálatokat 1980-86, valamint 1995-98. között végeztem a Mezőtúri Főiskolai Karon és az előzőekben megnevezett gazdaságokban.

a. A mérővizsgálat során alkalmazott mérőmüszerek és eszközök

A laboratóriumi méréseket saját tervezésű és kivitelezésü önitató-vizsgáló méröpulton végeztem el, melynek kapcsolási vázlatát az 1. ábra mutatja. 
1. ábra: A mérés kapcsolási vázlata

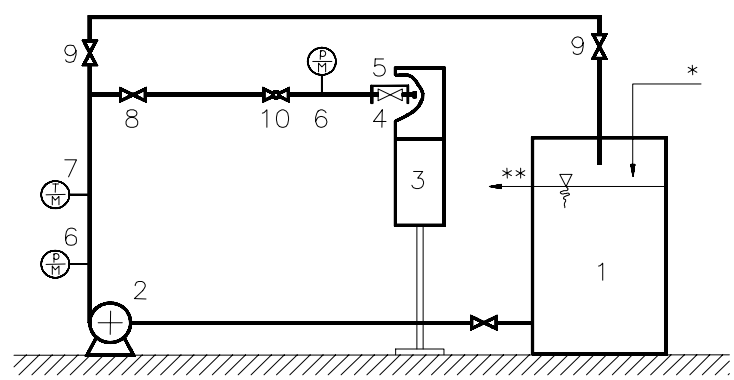

1. tárolótartály, 2. BVG 101/a típ. szivattyú, 3. hitelesített mérőedény, 4. mérendő önitatószelep, 5. csavarorsós beállító készülék, 6. manométer, 7. hőmérő, 8. átmeneti elzárószelep(1"), 9. átmeneti elzárószelep(1 1/2"), 10. AHA-MOFÉM golyóscsap, *központi hálózat, **túlfolyó

Figure 1: Measuring block for examination of self drinkers 1. cistern, 2. BVG 101/a type pump, 3. graduated jar, 4. valve of self drinker, 5. positioner, 6 . manometer, 7. thermometer, 8. shutoff valve (1"), 9. shut-off valve (1"”), 10. AHA-MOFÉM type cock, * water network, **overflow pipe

\section{A GYAKORLATBAN KÖZVETLENÜL HASZNOSÍTHATÓ EREDMÉNYEK}

- A létrehozott mérö- és vizsgáló egység (1. ábra) felhasználható az önitatók tervezésénél az alapvető paraméterek módosulásának gyors meghatározásához, ezáltal az egyes konstrukciók fejlesztésének, módosításának felgyorsitására.

- Az önitató-berendezések új vizsgálati módszerének általam történt kidolgozása alapul szolgálhat egy hazai vizsgálati és minősítési szabványnak.

- A vizsgált szelepek kiszerelt állapotban történt mérési eredményei alapján - azonos nyitási viszony esetén - legnagyobb átbocsátóképessége az SZI típusú önitató gumirugós szelepének van. Ugyanakkor - különösen nagyobb nyitási értékeknél - $\quad$ a szelep konstrukciójából következően $\zeta_{\mathrm{sz}}^{\prime}$-veszteségtényező is a legnagyobb értékü.

Mérési eredményeim, valamint ezen önitató hazai elterjedtsége késztetett a konstrukció mélyrehatóbb elemzésére és átalakítására a következő cél érdekében:

- $\zeta_{\mathrm{sz}}$ - veszteségtényező csökkentése,

- q - átbocsátóképesség növelése kisebb nyitási értékeknél,

illetve alacsonyabb nyomástartományban is.

A komplett szelep vizsgálatát és átalakítását három lépésben oldottam meg.

\section{a. A múanyag szelepszár módosítása}

A müanyag szelepszár kúposan kialakított végére ragasztással erősítették fel a gumirugót. A szelep összeszerelt állapotában - amint az a 2. ábrán is látható - a gumirugó alatt elhelyezkedö $1 \mathrm{~mm}$ szélességü váll a szelepszáron áramlástechnikailag kedvezötlen, mivel a keresztmetszet csökkentésével a víz beáramlását akadályozza.

Az átalakítás során ezt a vállat eltávolítottam és a szelepszár hornyos kiképzését annak teljes hosszában valósítottam meg.

\section{2. ábra: SZI típusú gumirugós önitató szelepszerkezete}

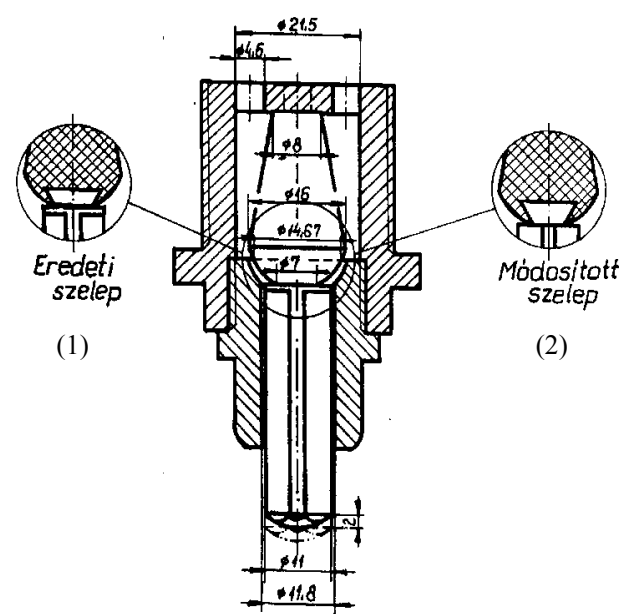

Figure 2: Rubber spring valve of self drinker type SZI original valve stem(1), modified valve stem(2)

\section{b. A szelepház beömlő furatainak növelése}

Az önitatószelep a vizet a 3. ábrán látható $4 \mathrm{db} \varnothing$ 4,6 mm-es furaton keresztül kapja.

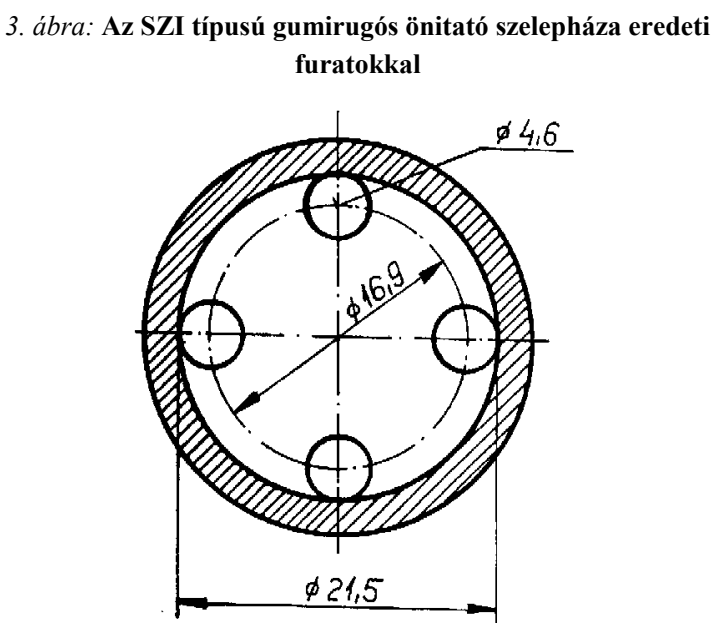

Figure 3: Valve body of rubber spring valve of self drinker type SZI with original holes

Az átfolyási keresztmetszetek kiszámítását az átalakított szelep esetében is minden szelepnyitási helyzetben elvégeztem.

$\mathrm{A} h / \mathrm{d}_{\mathrm{n}}=0,34$ és 0,39 nyitási értékeknél a beömlő $\varnothing 4,6 \mathrm{~mm}$-es négy furat keresztmetszete lett az átfolyás meghatározó, szük értéke.

Mindezeket figyelembe véve a műanyag szelepház beömlő furatainak keresztmetszetét a 4 . ábrán látható módon megnöveltem. 
Az ábra alapján oválisra készített furatok esetén a szelepház szilárdságilag is megfelelő marad és gyártása is egyszerüen megoldható. Ezzel az átalakítással a beömlö összes keresztmetszet $4 \mathrm{~A}=66$ $\mathrm{mm}^{2}$-röl 4A" = $100 \mathrm{~mm}^{2}$-re emelkedik.

4. ábra: Az SZI típusú gumirugós önitató szelepháza megnövelt furatokkal

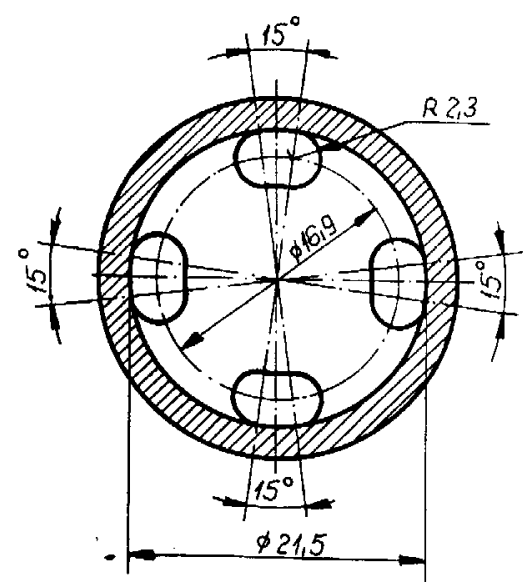

Figure 4: Valve body of rubber spring valve of self drinker type SZI with increased holes

\section{c. A mủanyag szelepház technológiailag helyesen, sorjamentesen kivitelezve}

Az általam vizsgált önitatók mindegyikénél a szelepház furatainál a gyártás során sorja keletkezett, melyet utólag nem távolítottak el. E gyártástechnológiai hibának szintén kisebb mértékü keresztmetszet-csökkentő hatása van, amelyet mérési eredményeim is igazoltak. A vizsgálat során az előzőekben említett sorját eltávolítottam.

$\mathrm{Az}$ átalakítás eredményeként a szelepszár módosítása és a szelepház beömlő furatainak növelése a szelep veszteségtényezőjének csökkenését és az átbocsátóképesség igen jelentős növekedését eredményezte.

$\mathrm{Az}$ átalakított gumirugós szelep vizsgált variációinak összehasonlítását a minimális nyitási viszonynál az 5. ábra mutatja.

E konstrukciós változtatással elértem, hogy a szelep általam mért közepes nyitási viszonyánál is $\left(\mathrm{h} / \mathrm{d}_{\mathrm{n}}=0,34\right)$ a hazai telepekre jellemző nyomástartományban biztosítva legyen a szarvasmarha részére szükséges vízmennyiség. Így az állat már a közepes nyitási viszonynál is szürcsölésmentesen, ivási sebességének megfelelö vízutánpótlással jut az ivóvizéhez.

- A szelepes rendszerü önitatók átbocsátóképességének a szelepek kiszerelt állapotában való mérései alapján az SZI típusú önitató acélrugós szelepének átbocsátóképessége a vizsgált tartományban nem megfelelö.

- A szelepes önitatók feltöltődési idejére vonatkozó vizsgálati eredmények alapján legkedvezőbb paraméterekkel a gumirugós és a gumihevederes önitatók rendelkeznek. A szelepes önitatók csészéinek hasznos térfogata mindegyik hazai típusnál 2 1, mely értéket a szarvasmarha ivásfolyamata szempontjából kevésnek tartom.

- A szinttartásos rendszerü berendezések közül az egyedi itatást biztosító NIVÓ típusú önitatók alacsony átbocsátóképességük és kis vízterük miatt szarvasmarha itatására nem alkalmasak.

- A szinttartásos önitatók mérési eredményeinek felhasználásával kísérleti, védőkorláttal ellátott egyedi szinttartásos rendszerű önitatót alakítottunk ki kollegáimmal. Az itatóedény növelt hasznos térfogata és szelepfurata laboratóriumi és üzemi méréseim szerint biztosítja a kötött tartástechnológiában két állat részére szükséges ivóvízellátást, megfelelő körülmények között. A berendezés több tehenészeti telepre is beépítésre került.

- A tartós üzemi vizsgálatok alapján megállapítottam, hogy a szelepes berendezések közül legjobb üzembiztossági mutatókkal a gumihevederes és a gumirugós önitatók rendelkeznek. (1. táblázat) Ez alátámasztja a gumi alkalmazásának létjogosultságát a különböző szelepszerkezeteknél, melyet a külföldi országokban már elterjedten alkalmaznak.

A szinttartásos önitatók közül a csoportos berendezések mutatói kedvezőbbek, mint az egyedi szelepeseké, ami az egyszerübb és a más területen is jól bevált, nagy áteresztőképességü Jakabúszógolyós szelepszerkezettel magyarázható.
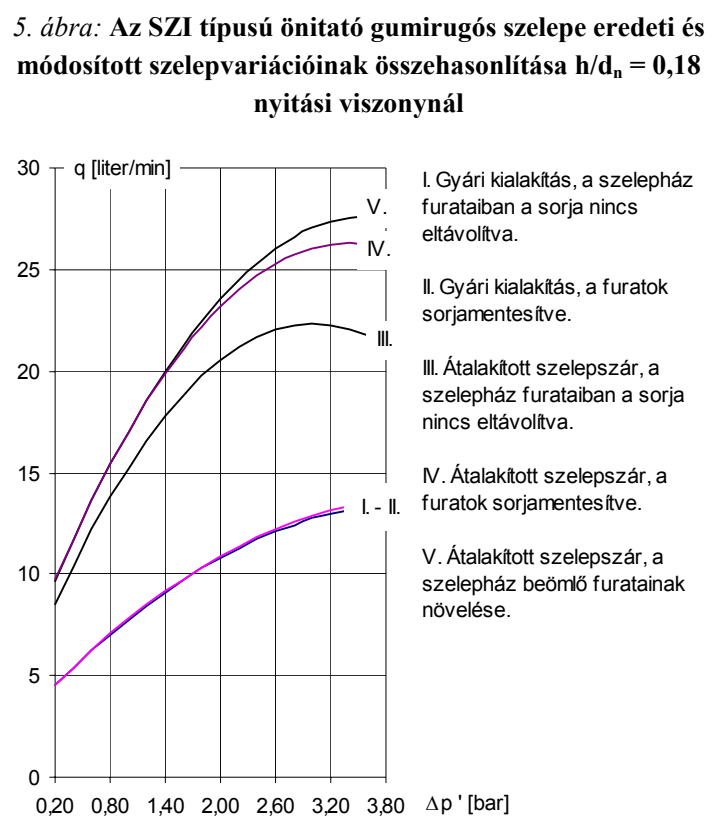

Figure 5: Comparison of SZI self drinkers with original and modified rubber valve at $h / d_{n}=0,18$ opening valve

I. Factory version, flash is not removed from the holes of valve housing, II. Factory version, flash removed from holes, III. Modified valve stem, flash is not removed from the holes of valve housing, IV. Modified valve stem, flash removed from holes, V. Modified valve stem, the inlet holes of the valve housing are increased 
A vizsgált berendezések üzembiztossági mutatói

\begin{tabular}{|ll|r|r|r|}
\hline \multicolumn{1}{|c|}{ Önitató típusa(7) } & \multicolumn{2}{c|}{$\begin{array}{c}\text { Technológiai } \\
\text { üzembiztosság } \\
\mathbf{K}_{\mathbf{4 1}}(\mathbf{8})\end{array}$} & $\begin{array}{c}\text { Múszaki } \\
\text { üzembiztosság } \\
\mathbf{K}_{\mathbf{4 3}}(\mathbf{9})\end{array}$ & $\begin{array}{c}\text { Üzembiztosság } \\
\mathbf{K}_{\mathbf{4}}(\mathbf{1 0})\end{array}$ \\
\hline 1. & SZI típ. Acélrugós önitató(3) & 0,96 & 0,93 & 0,90 \\
\hline 2. & SZI típ. Gumirugós önitató(4) & 0,98 & 0,96 & 0,94 \\
\hline 3. & D-01 típ. Acélrugós önitató(5) & 0,97 & 0,95 & 0,92 \\
\hline 4. & P-1 típ. Gumihevederes önitató(6) & 0,98 & 0,99 & 0,98 \\
\hline 5. & NÍVÓ típ. Egyedi szinttartásos önitató(1) & 0,96 & 0,97 & 0,93 \\
\hline 6. & PCSSZ-II. típ. Csoportos szinttartásos önitató(2) & 0,99 & 0.98 & 0,97 \\
\hline
\end{tabular}

Table 1: Values of reliability of equipment tested

Level controlled individual watering equipment type NÍVÓ (1), level controlled group watering equipment type PCSSZ-II (2), steel spring valve of self drinker type SZI (3), rubber spring valve of self drinker type SZI (4), steel spring valve of self drinker type D-O1 (5), rubber stripped self drinker type P-1 (6), serial number and type of the self drinker (7), technological reliability (8), technical reliability (9), reliability (10)

\section{4. ÚJ TUDOMÁNYOS EREDMÉNYEK}

1. A szelepek átbocsátóképessége $[1 / \mathrm{min}]$ a nyomás $[\mathrm{Pa}]$ függvényében $\left(\mathrm{q}=\mathrm{f}\left(\Delta \mathrm{p}^{\prime}\right) \quad[\mathrm{l} / \mathrm{min}]\right)$ exponenciális összefüggés szerint változik $(6$. ábra), de csak a legnagyobb áteresztőképességü értékelhető úgy, hogy eléri a kifejlett szarvasmarha számára szükséges ivási sebesség biztosítását.

6. ábra: A vizsgált szelepek átbocsátóképességének összehasonlítása azonos nyitási viszonynál $\left(h / d_{n}=0,31\right)$ h - szelepemelkedés [mm], $d_{n}$ - a szelep névleges átmérője [mm]

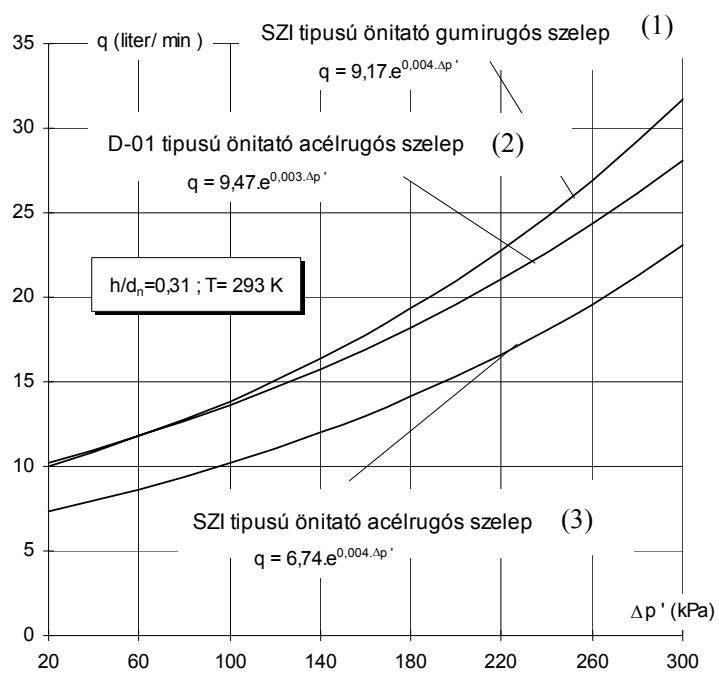

Figure 6: Comparison of output data of valves tested at identical opening valve $\left(h / d_{n}=0,31\right)$

$h$-valve displacement $[\mathrm{mm}], d_{n}$-nominal diameter of the valve Rubber spring valve of self drinker type SZI(1), Steel spring valve of self drinker type D01(2), Steel spring valve of self drinker type SZI(3)
2. A szelepek veszteségtényezői $\left(\zeta_{\mathrm{sz}}^{\prime}\right)$ és a nyitási viszony $\left(\mathrm{h} / \mathrm{d}_{\mathrm{n}}\right)$ összefüggése a hagyományos konstrukciójú önitató szelepeknél $\left(\zeta_{\mathrm{sz}}^{\prime}=\mathrm{f}\left(\mathrm{h} / \mathrm{d}_{\mathrm{n}}\right)\right)$ exponenciális. $\quad\left(\zeta_{\mathrm{sz}}^{\prime}=3,65 \cdot \mathrm{e}^{-0,65\left(\mathrm{~h} / \mathrm{d}_{\mathrm{n}}\right)}\right) \quad(7$. ábra). A gumirugós kivitelek veszteségtényezője követi ugyan ezt az összefüggést, viszont a nyitási viszony növekedésével rohamosan változik a veszteségtényező is, ami a gumirugó nem kívánt deformációjának következménye.

7. ábra: A D-01 típusú önitató szelepének veszteségtényezője a nyitási viszony függvényében $\left(\Delta \mathrm{p}^{\prime}=2 \cdot 10^{4}-14 \cdot 10^{4} \mathrm{~Pa}\right)$

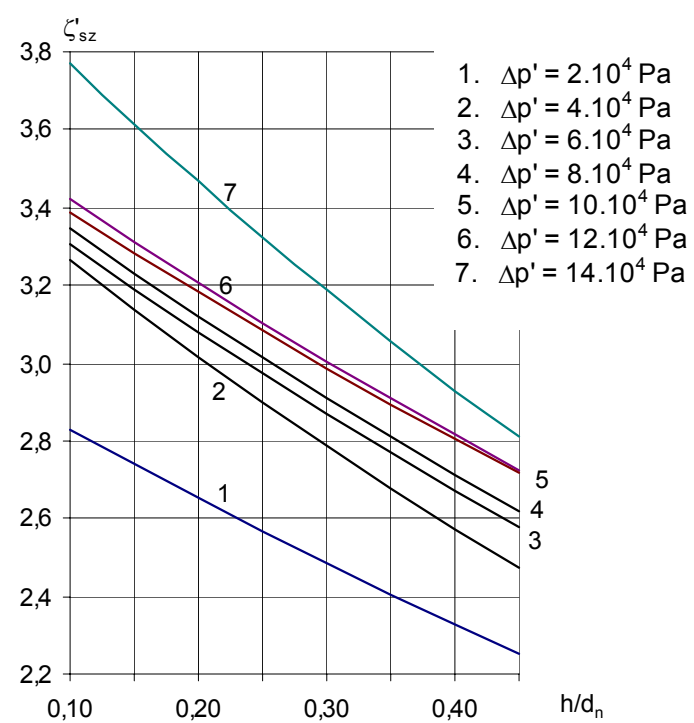

Figure 7: Loss factor of steel spring valve of self drinker type D-01 independent of opening

3. Összehasonlítás esetén a $\mathrm{k}_{\mathrm{v}}$ - szelepállandó a különféle típusú szelepek alkalmazhatóságát (müködési funkciót) jól jellemzi $\left(\mathrm{k}_{\mathrm{v}}=\mathrm{f}\left(\mathrm{h} / \mathrm{d}_{\mathrm{n}}\right)\right.$ $\left[\mathrm{m}^{3} / \mathrm{h}\right]$.

Az értékelés egyik alapvető támpontját szolgáltatja. 
A $\mathrm{k}_{\mathrm{v}}$ - szelepállandó azt a vízmennyiséget jelenti, amelyik $\Delta_{\mathrm{p}}=98,1 \mathrm{kPa}$ nyomásesés mellett $(\mathrm{Q}=$ $1000 \mathrm{~kg} / \mathrm{m}^{3}$ ) a szerelvényen óránként átáramlik. $\mathrm{Az}$ összehasonlításból következően tett megállapítást a szelepek állandóinak $\left(\mathrm{k}_{\mathrm{v}}\right)$ értékei is alátámasztják, mely értékeket számítással és méréssel is meghatároztam.
4. A vizsgált alapvető paraméterek szerint az aktív szelepes itatók a nagy állatok (szarvasmarha, ló) ivási igényeit nem, vagy csak igen nagy kompromisszumok elfogadása révén képesek kielégíteni. Ezért a vízhálózat módosítása nélkül a vízszint szabályozású (szinttartásos rendszerü) nyílt vízterü önitatókat célszerü alkalmazni.

\section{IRODALOM}

Boxberger, I.-Zips, K. (1979): Untersuchungen zur Trinkwasseraufnahme von Milchkühen im Laufstall. In: Landtechnik, 7/8. 361-364.

Castle, M. E.-Thomas, T. P. (1975): The water intake of British Fricsian cows on rations containing various. In: Animal Production, 2. 181-189.

Dávidházy G. (1980): Egyedi szinttartásos rendszerủ, vedres itatócsészés szarvasmarha itatóberendezés kialakítása. In: IV. Állattenyésztési és Takarmányozási Tudományos Termelési Tanácskozás, Budapest

Dávidházy G. (1982): A nagyüzemi szarvasmarhatartásban használatos itatóberendezések konstrukciós és hidromechanikai vizsgálata. Doktori értekezés. GATE Gépészmérnöki Kar, Gödöllö, 135.

Dávidházy G. (1983): A nagyüzemi szarvasmarhatartásban használatos itatóberendezések konstrukciós és hidromechanikai vizsgálata. In. DATE MGFK Évkönyve és Tudományos Közleményei, Mezőtúr, 42-43.

Dávidházy G. (1984): A nagyüzemi szarvasmarhatartásban használatos itatóberendezések konstrukciós és hidromechanikai vizsgálata. In. DATE Tudományos Közleményei XXIV. Különlenyomat, Debrecen, 87-512.

Dávidházy G. (1985): A tejgazdaságok üzemeltetésének tapasztalatai Magyarországon. In. A mezőgazdasági gépek és berendezések tárgykörü III. Nemzetközi Konferencia, Plock

Dávidházy G. (1986): Tehenészeti telepek gépesítési kérdéseinek vizsgálata. In. Tessedik Sámuel Tiszántúli Mezőgazdasági Tudományos Napok, Debrecen, 162-163.

Dávidházy G. (1993): Családi gazdaságok üzemeltetésének külföldi és hazai vizsgálata. In: XXX. Országos Mezőgazdasági Gépesítési Tanácskozás, Szekszárd, 70-65.

Dávidházy G. (1995): Önitatók műszaki paraméterei. (G. Dávidházy: Specifikation of drinkers, Lektorálta: Dr. Tóth L.) In: Mezőgazdasági Technika, XXXVI. 10. 2-4.

Dávidházy G. (1996): Önitatók műszaki paraméterei. In. MTAAMB Kutatási és Fejlesztési Tanácskozás, Gödöllő, 30.

Dávidházy G. (1997): Önitatók vizsgálatának eredményei. In. MTA-AMB Kutatási és Fejlesztési Tanácskozás, Gödöllő, 36.

Dávidházy G.-Dolina K. (1976): A nagyrévi Tiszazug MGTSZ 224 fh-es tehénistállójának rekonstrukciós terve. Tanulmányterv, DATE MGFK, Mezőtúr

Dávidházy G.-Patkós I. (1974): Zárt, kötött tartású, tömbösített tehenészeti telep (Fejőházi fejéssel, Középtiszai Állami
Gazdaság). In: Értesítő termeléstechnológiák müszaki vizsgálatáról, 62.40

Dávidházy G.-Patkós I. (1975): Zárt, kötetlen tartású, húshasznosítású tehenészeti telep („Lenin” Mg. Tsz. Endrőd). In: Értesító termeléstechnológiák müszaki vizsgálatáról, 72. 48.

Dávidházy G.-Varga K. (1980): A nagyüzemi és háztáji termelés technikai-technológiai fejlesztése. Tanulmányterv (Társszerzők: Vizdák K.-Király J.) DATE MGFK, Mezőtúr, 78.

Dávidházy, G. (1994): Home and abroad examination of family operation. In: Hungarian Agricultural Engineering, 7. 50-51.

Gere T. (1996): Állattenyésztés. Alapismeretek. Mezőgazda Kiadó, Budapest

Horn P. (1995): Állattenyésztés 1. Mezőgazda Kiadó, Budapest

Kocsis P. (1981): A szarvasmarha ivóvízellátásának összehasonlító vizsgálata, különös tekintettel az itatóberendezésekre. Kandidátusi értekezés, Gödöllő

Komjáthy Gy.-Maknics Z.-Márkó J.-Mentes K.-Racskó P.-Tímári L. (1996): Állattenyésztési ismeretek. Mezőgazdasági Szaktudás Kiadó, Budapest

Metzner, R. (1978): Trinkverhalten des Rindestechnisch richtig umsetzen. In: Landtechnik, 9. 386-390.

Mikecz I. (1985): Az állattenyésztés gépei. Mg. Kiadó, Budapest

Mikecz I.-Czakó I. (1977): Adatok a szarvasmarha ivásához és vízfogyasztásának mérési módszeréhez. In: Állattenyésztés, 26. 3.

Patkós I.-Tóth L. (1978): A szarvasmarhatartás gépesítése. Mg. Kiadó, Budapest

Schmidt J. (1995): Gazdasági állataink takarmányozása. Mezőgazda Kiadó, Budapest

Szendrő P. (1993): Mezőgazdasági géptan. Mezőgazda Kiadó, Budapest

Szmodits T. (1990): A Holstein-Fríz Magyarországon. Szerk.: Szaleczky L. Akadémiai Kiadó, Budapest

Tóth L. szerk. (1998): Állattartási technika. Mg. Szaktudás Kiadó, Budapest

The GOOD (1998): Program SUEVIA Drinking Bowls and Drinkers for Cattle. ANONYM, Hereford: Hanco National Cattle Supplies

The JUG (1996) Livestock Waterer. ANONYM, Waterford: Edstrom Industries, INC 